\title{
Sulodexide Reduces the Proinflammatory Effect of Serum from Patients with Peripheral Artery Disease in Human Arterial Endothelial Cells
}

\author{
Patrycja Sosińska ${ }^{a}$ Ewa Baum ${ }^{a}$ Beata Maćkowiak ${ }^{a}$ Magdalena Maj ${ }^{b}$ \\ Katarzyna Sumińska-Jasińska ${ }^{a}$ Ryszard Staniszewski ${ }^{b} \quad$ Andrzej Bręborowicz ${ }^{a}$ \\ aDepartment of Pathophysiology, Poznan University of Medical Sciences, bepartment of Vascular and \\ General Surgery, Poznan University of Medical Sciences, Poznan, Poland
}

\section{Key Words}

Human arterial endothelial cells $\bullet$ Peripheral artery disease $\bullet$ Sulodexide $\bullet$ Inflammation

\begin{abstract}
Background/Aims: Dysfunction of the arterial endothelial cells promotes the progression of atherosclerosis. We studied how exposure of human arterial endothelial cells to atherosclerotic serum from patients with peripheral artery disease changes the secretory activity of these cells, and whether that reaction is modified by sulodexide. Methods: Endothelial cells in in vitro culture were exposed to standard culture medium $\pm 100 \mathrm{pg} / \mathrm{mL}$ Interleukin-1(IL-1) or to medium supplemented with $20 \%$ atherosclerotic serum. Afterwards, the expression of genes responsible for the synthesis of Interleukin-6 (IL-6), Vascular Cell Adhesion Protein-1 (VCAM-1) and Von Willebrand Factor (VWF) was evaluated, together with the secretion of these compounds. Additionally, the effect of sulodexide on these processes was studied. Results: Atherosclerotic serum stimulated the expression of IL6, VCAM-1 and VWF genes in endothelial cells, which was followed by increased secretion of these compounds by $179 \%$, $121 \%$ and $116 \%$, respectively. Sulodexide $(0.5 \mathrm{LRU} / \mathrm{mL})$ reduced atherosclerotic serum induced increased expression of genes for IL-6 (-32\%), VCAM-1 (-20\%) and VWF (-42\%), and lowered secretion of these molecules: IL-6 (-27\%), VCAM-1(-27\%), VWF (-25\%). Sulodexide also reduced, in a dose- dependent manner, secretion of IL 6 from unstimulated and stimulated with IL-1 endothelial cells. Conclusions: Atherosclerotic serum induces proinflammatory and prothrombotic phenotype in arterial endothelium, which is partially reduced by sulodexide, via inhibition of genes expression, and in consequence lower secretory activity.

\section{Introduction}

Endothelium lining the arteries is not only a barrier which regulates the transport of small and large molecules, but also plays an important role in the regulation of the peripheral blood flow and maintenance of intravascular homeostasis. Disturbed endothelial 


\section{Cellular Physiology Cell Physiol Biochem 2016;40:1005-1012 \begin{tabular}{l|l|l|}
\hline DOI: 10.1159/000453157 & $\begin{array}{l}\text { C) } 2016 \text { The Author(s). Published by S. Karger AG, Basel } \\
\text { www.karger.com/cpb }\end{array}$
\end{tabular} \\ Sosińska et al.: Arterial Endothelium and Sulodexide}

function results in increased intravascular inflammatory reaction, impaired fibrinolysis and enhanced blood clotting [1]. All these changes initiate the development and progression of atherosclerosis. It was hypothesized that damage to glycocalyx, which is a mixture of glycosaminoglycans on the surface of the endothelial cells, is one of the first steps leading to atherothrombotic changes in the arterial wall [2]. Recently, Cancel and co-workers have shown that the shedding of glycocalyx in the endothelial cells facilitates the adhesion of monocytes and macrophage infiltration, promoting lipids deposition and the development of atherosclerotic plaques [3]. Hyperglycemia in patients with type 2 diabetes causes damage to the endothelial glycocalyx, and treatment with sulodexide restores the glycocalyx, which results in reduced vascular permeability to albumin [4].

Sulodexide is a mixture of glycosaminoglycans with a documented antiinflammatory, profibrynolytic and lipid lowering activity [5-7]. It is used in the treatment of chronic venous disease [5] and in arterial diseases [8]. Endothelial cells' properties are changed upon their exposure to sulodexide. We found in human venous endothelial cells in in vitro culture reduced intracellular generation of free radicals, and the release of IL- 6 and MCP- 1 during their exposure to sulodexide [9]. In another study we demonstrated that sulodexide reduced the proinflammatory effect of serum from patients with chronic venous disease on human venous endothelial cells [10]. Despite the fact that sulodexide exhibits good therapeutic effects in conditions of atherosclerosis, such as prevention of arterial thrombosis [11], inhibition of smooth muscle cells proliferation [12], and reduction of endothelial cells desquamation during repeated exposure to adrenaline [13], there is little information about its effect on human arterial endothelial cells. Reports describing the in vitro effect of sulodexide on endothelial cells come from experiments performed on human venous endothelial cells [9, $10,14]$. We found that the secretory activity of human aortic endothelial cells is different from that observed in human endothelial venous cells (unpublished data).

In this paper we present the results of experiments on human arterial endothelial cells exposed to serum from patients with peripheral arteries disease (PAD). Changes in the secretory properties of these cells are described after their treatment with serum alone or with serum supplemented with sulodexide.

\section{Material and Methods}

The study was performed on human aortic endothelial cells (HAEC) purchased from Life Technologies Corporation, (Carlsbad, USA). Cell cultures were established in medium M200 supplemented with 2\% fetal bovine serum, hydrocortisone $1 \mu \mathrm{g} / \mathrm{ml}$, human epidermal growth factor $10 \mathrm{ng} / \mathrm{ml}$, basic fibroblast growth factor $3 \mathrm{ng} / \mathrm{ml}$, heparin $10 \mu \mathrm{g} / \mathrm{ml}$ (all chemicals from Life Technologies Corporation, Carlsbad, USA). All disposable equipment for cell culture was purchased from Nunc A/S (Denmark). Cells were cultured at $37^{\circ} \mathrm{C}$ and in $5 \% \mathrm{CO}_{2}$ air atmosphere.

\section{Analysis of the cells' secretory activity}

The secretory activity of HAEC was studied in the presence of standard culture medium or in medium supplemented with $20 \%$ mixed serum obtained from 10 patients with peripheral artery disease (PAD), stages III and IV Fontaine's classification. The mean concentration of IL6 in studied serum was $4.1 \pm 1.3$ $\mathrm{pg} / \mathrm{mL}$. The effect of sulodexide on the secretion of the studied molecules from HAEC was studied in unstimulated cells or cells stimulated with interleukin-1 $(100 \mathrm{pg} / \mathrm{mL})$ or with mixed PAD serum.

For the evaluation of changes of the secretory properties of HAEC, in all experiments cell monolayers were exposed for 24 hours to the studied factor, and afterwards the medium was removed. For the next 24 hours incubation was started in serum-free culture medium. At the end of that incubation supernatant was collected for measurement of the studied molecules composition:

- Interleukin 6 (ELISA kit, R\&D, Minneapolis, USA)

- Von Willebrand Factor (VWF) (ELISA kit, Sigma-Aldrich, St. Louis, USA) 


\section{Cellular Physiology Cell Physiol Biochem 2016;40:1005-1012 \begin{tabular}{ll|l} 
DOI: 10.1159/000453157 & $\begin{array}{l}\text { O 2016 The Author(s). Published by S. Karger AG, Basel } \\
\text { www.karger.com/cpb }\end{array}$
\end{tabular} \\ Sosińska et al.: Arterial Endothelium and Sulodexide}

- Vascular Cell Adhesion Protein -1 (VCAM-1) (ELISA kit, Sigma-Aldrich, St. Louis, USA).

Secretion of the studied molecules was expresses per number of the cells in the well.

Effect of sulodexide on secretion of IL6 from unstimulated and stimulated with IL-1 HAEC. HAEC monolayers in 48-well plates were exposed for 24 hours to the following solutions:

- Standard culture medium - Control

- Standard culture medium + Sulodexide 0.125 LRU/mL

- Standard culture medium + Sulodexide $0.5 \mathrm{LRU} / \mathrm{mL}$

- Standard culture medium + IL-1 $100 \mathrm{pg} / \mathrm{mL}$

- Standard culture medium + IL-1 $100 \mathrm{pg} / \mathrm{mL}+$ Sulodexide $0.125 \mathrm{LRU} / \mathrm{mL}$

- Standard culture medium + IL-1 $100 \mathrm{pg} / \mathrm{mL}$ + Sulodexide $0.5 \mathrm{LRU} / \mathrm{mL}$

At the end of the secondary incubation in serum-free medium, supernatants were collected for the measurement of IL-6. Cells were harvested from the wells with trypsin 0.05\%-EDTA $0.02 \%$ solution and their number was counted in a hemocytometer.

Effect of PAD serum and Sulodexide on secretion of the inflammatory mediators from HAEC. Monolayers of HAEC in 48-well culture plates were exposed for 24 hours to the following solutions:

- Standard culture medium - Control

- Standard culture medium + Sulodexide 0.5 LRU/mL

- Standard culture medium $+20 \%$ PAD serum

- Standard culture medium + 20\% PAD serum + Sulodexide $0.5 \mathrm{LRU} / \mathrm{mL}$

At the end of the secondary 24 hours' incubation in serum-free medium, supernatants were collected for measurement of IL-6, VCAM-1 and VWF. Cells were harvested from the wells with trypsin 0.05\%-EDTA $0.02 \%$ solution, and their number was counted in a hemocytometer.

\section{Analysis of genes expression}

Experiments were performed on HAEC monolayers in $25 \mathrm{~cm}^{2}$ culture flasks for analysis of the genes expression, or in 48-well plates for measurement of the secretory activity of the cells.

HAEC monolayers were incubated for 24 hours in the following media:

- Standard culture medium

- Standard culture medium supplemented with sulodexide $0.5 \mathrm{LRU} / \mathrm{mL}$

- Standard culture medium supplemented with 20\% PAD serum

- Standard culture medium supplemented with 20\% PAD serum and sulodexide $0.5 \mathrm{LRU} / \mathrm{mL}$

After exposure, total RNA from cells was isolated using the TRIzol reagent (Invitrogen-Life Technologies, Poland) method according to the manufacturer's instructions. RNA samples were treated with DNase I using DNA-free DNase Treatment and Removal Reagent (Ambion). RNA quality and concentration were assessed by spectrophotometry using a NanoDrop (NanoDrop, Thermo Scientific, DE, USA).

Two micrograms of total RNA were reverse-transcribed to cDNA using the BioScript All-in One cDNA Synthesis Super Mix (Biotool.com). Relative levels of mRNA of 3 genes of interest: Interleukin -6 [IL6], Vascular Cell Adhesion Molecule 1 [VCAM1] and Von Willebrand Factor [VWF] were analyzed using Sybr green real-time quantitative PCR (Applied Biosystems) in triplicates and normalized to levels of internal house-keeping genes: glyceraldehyde-3-phosphate dehydrogenase (GAPDH), $\beta$ - actin (ACT $\beta$ ) and hypoxanthine phosphoribosyltransferase 1 (HPRT).

Specific primers for the amplification of each gene were designed using Primer-BLAST [15]. Primer characteristics are presented in Table 1.

The PCR parameters were as follows: initial denaturing for $10 \mathrm{~min}$ at $95^{\circ} \mathrm{C}$, followed by 35 cycles of denaturation $\left(95^{\circ} \mathrm{C}\right.$ for $\left.10 \mathrm{~s}\right)$, annealing $\left(58^{\circ} \mathrm{C}\right.$ for $\left.45 \mathrm{~s}\right)$ and extension $\left(60^{\circ} \mathrm{C}\right.$ for $\left.20 \mathrm{~s}\right)$. After completed realtime PCR reactions, a melting curve analysis was performed for each sample to confirm that a single, specific product was generated. Relative gene expression was calculated using the 2- $\Delta \Delta \mathrm{Ct}$ method [16].

\section{Statistical analysis}

Results are presented as mean \pm SD. Analysis of the data was performed with One way analysis of variance with the post hoc Newman Keuls test. A p value of less than 0.05 was considered significant. 
Table 1. Characteristics of primers used in the study

\begin{tabular}{|c|c|c|c|c|}
\hline Gene & Name & Accession \# & $\begin{array}{c}\text { Amplicon length } \\
\text { (bp) }\end{array}$ & Primer sequence $\left(5^{\prime} \rightarrow 3^{\prime}\right)$ \\
\hline GAPDH & $\begin{array}{l}\text { glyceraldehyde-3-phosphate } \\
\text { dehydrogenase }\end{array}$ & NM_002046 & 231 & $\begin{array}{l}\text { F:TTCGTCATGGGTGTGAACC } \\
\text { R:GATGATGTTCTGGAGAGCCC }\end{array}$ \\
\hline ACT $\beta$ & $\beta$ - actin & NM_001101 & 203 & $\begin{array}{l}\text { F: GGCATCCTCACCCTGAAGTA } \\
\text { R: GGGTGTTGAAGGTCTCAAA }\end{array}$ \\
\hline HPRT & $\begin{array}{l}\text { hypoxanthine phosphoribosyl- } \\
\text { transferase } 1\end{array}$ & NM_000194 & 192 & $\begin{array}{l}\text { F:TGCTCGAGATGTGATGAAGG } \\
\text { R: TCCCCTGTTGACTGGTCATT }\end{array}$ \\
\hline IL6 & interleukin 6 & NM_000600 & 167 & $\begin{array}{l}\text { F: ATGCAATAACCACCCCTGAC } \\
\text { R: AGGTGCCCATGCTACATTT }\end{array}$ \\
\hline VCAM1 & vascular cell adhesion molecule 1 & NM_001078 & 201 & $\begin{array}{l}\text { F:GTTGAAGGATGCGGGAGTAT } \\
\text { R:TTCATGTTGGCTTTTCTTGC }\end{array}$ \\
\hline VWF & Von Willebrand factor & NM_000552 & 232 & $\begin{array}{l}\text { F:CCAGATTTGCCACTGTGATG } \\
\text { R: AAGGCCTTCAGCACTTCAA }\end{array}$ \\
\hline
\end{tabular}

Fig. 1. Release of IL-6 from unstimulated HAEC incubated in control medium (CON) or in medium supplemented with sulodexide in concentration $0.125 \mathrm{LRU} / \mathrm{mL}$ (S 0.125) or $0.5 \mathrm{LRU} / \mathrm{mL}$ (S 0.5) (** $\mathrm{p}<0.01$ vs. CON; ${ }^{* * *} \mathrm{p}<0.001$ vs. CON). On the right side of the graph release of IL-6 from HAEC exposed to medium supplemented with interleukin-1 100pg/ $\mathrm{ml}$ (IL-1) or simultaneously to IL-1 and sulodexide in concentration $0.125 \mathrm{LRU} / \mathrm{mL}$ (S 0.125) or $0.5 \mathrm{LRU} /$ $\mathrm{mL}$ (S 0.5) (\#\#\# p<0.001 vs. IL-1).

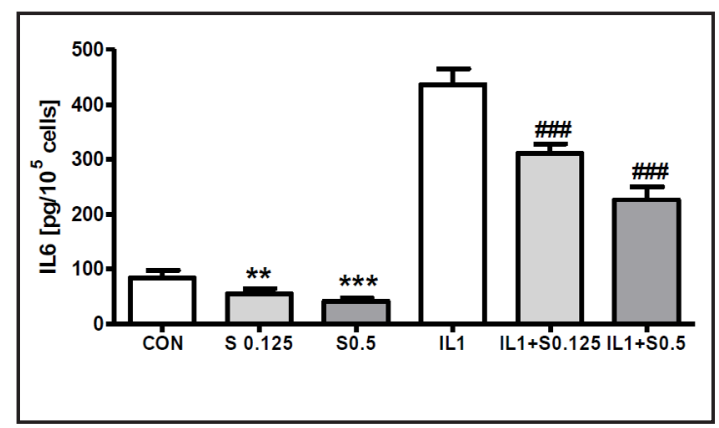

\section{Results}

Sulodexide causes dose-dependent inhibition of the inflammatory response, measured with a release of IL6 in the endothelial cells cultured in standard medium or in medium supplemented with interleukin- $1 \beta(100 \mathrm{pg} / \mathrm{mL})$ (Fig. 1).

We found that sulodexide used in a dose of $0.5 \mathrm{LRU} / \mathrm{mL}$ as a supplement to standard culture medium, caused in HAEC reduced expression of genes responsible for the synthesis of IL-6 (- 36\%), VCAM-1 (- 19\%) and VWF (- 86\%) (Fig. 2). During the subsequent 24 hours, when the cells were incubated in serum-free medium without sulodexide, the secretion of the studied molecules was lower than in the control, untreated group. Synthesis of IL6 was reduced by $18 \%$, p $<0.05$ as compared to control cells (Fig. 3). HAEC pre-exposed to sulodexide also produced less VCAM-1 (-24\%, p<0.05) (Fig. 4) and less VWF $(-21 \%, \mathrm{p}<0.001)$ (Fig. 5), as compared to control cells.

Endothelial cells exposed for 24 hours to culture medium supplemented with $20 \%$ serum from patients with PAD released more studied inflammatory mediators during the wash-out period as compared to cells cultured in control medium. Release of IL6 was increased by $179 \%$ ( $\mathrm{p}<0.001$ vs. control), of VCAM- 1 by $121 \%$ ( $<<0.01$ vs. control), and of VWF by $116 \%$ ( $\mathrm{p}<0.001 \mathrm{vs.} \mathrm{control).} \mathrm{However,} \mathrm{when} \mathrm{the} \mathrm{cells} \mathrm{were} \mathrm{simultaneously} \mathrm{exposed} \mathrm{to}$ $20 \%$ PAD serum and sulodexide $0.5 \mathrm{LRU} / \mathrm{ml}$, the release of these mediators was significantly reduced by $27 \%$ for IL6 (Fig. 3), by $28 \%$ for VCAM-1 (Fig. 4), and by $25 \%$ for VWF (Fig. 5), as compared to cells exposed to PAD serum.

HAEC exposed for 24 hours to medium with 20\% PAD serum demonstrated an increased expression of genes regulating the synthesis of IL6 (+163\% vs. control), VCAM-1 (+141\% vs. control) and VWF ( $+140 \%$ vs. control) (Fig. 2$)$. In the presence of sulodexide $(0.5 \mathrm{LRU} / \mathrm{mL})$ added to such medium, the expression of these genes was lower: $-32 \%$ for IL6, $-20 \%$ for VCAM-1 and $-42 \%$ for VWF, as compared to cells treated with 20\%PAD serum alone (Fig. 2). 


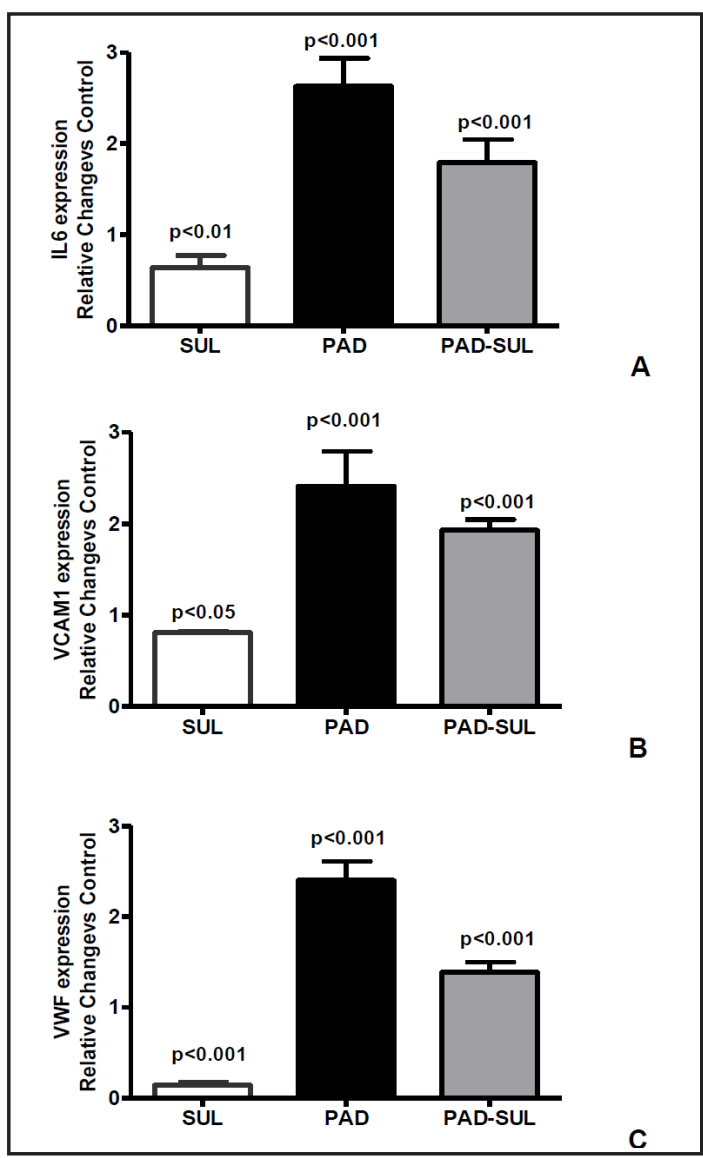

Fig. 2. Relative expression (fold change), vs. standard culture medium, of IL6,(A) VCAM-1(B) and VWF (C) genes in HAEC exposed to standard culture medium supplemented with sulodexide $0.5 \mathrm{LRU} / \mathrm{mL}$ (SUL) or with $20 \%$ PAD serum (PAD) or with $20 \%$ PAD serum and sulodexide $0.5 \mathrm{LRU} / \mathrm{mL}$ (PAD-SUL). Statistical significance vs. standard culture medium used as control is shown.

Fig. 5. Release of VWF from HAEC preincubated in control medium (CON) or in medium supplemented with sulodexide $0.5 \mathrm{LRU} / \mathrm{mL}$ (CON-SUL). On the right side of the graph release of VWF from HAEC preincubated in medium containing $20 \%$ of PAD serum (Serum) or in the same medium, additionally supplemented with Sulodexide $0.5 \mathrm{LRU} / \mathrm{mL}$ (Serum+SUL).

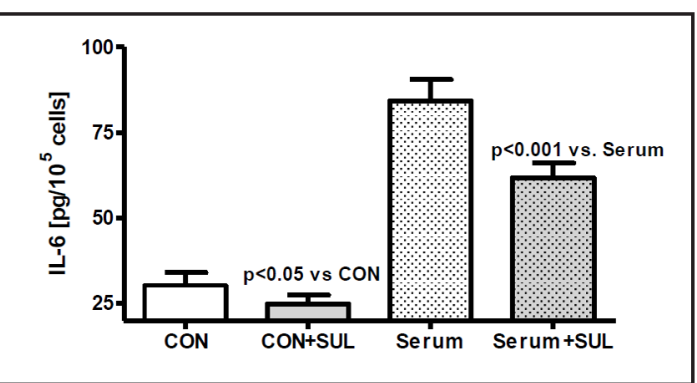

Fig. 3. Release of IL-6 from HAEC preincubated in control medium (CON) or in medium supplemented with sulodexide $0.5 \mathrm{LRU} / \mathrm{mL}$ (CON-SUL). On the right side of the graph release of IL6 from HAEC preincubated in medium containing $20 \%$ of PAD serum (Serum) or in the same medium, additionally supplemented with Sulodexide $0.5 \mathrm{LRU} / \mathrm{mL}$ (Serum+SUL).

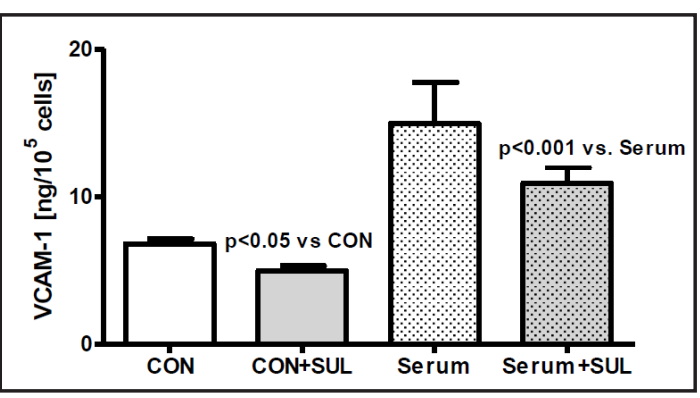

Fig. 4. Release of VCAM-1 from HAEC preincubated in control medium (CON) or in medium supplemented with sulodexide $0.5 \mathrm{LRU} / \mathrm{mL}$ (CON-SUL). On the right side of the graph release of VCAM-1 from HAEC preincubated in medium containing $20 \%$ of PAD serum (Serum) or in the same medium, additionally supplemented with Sulodexide $0.5 \mathrm{LRU} / \mathrm{mL}$ (Serum+SUL).

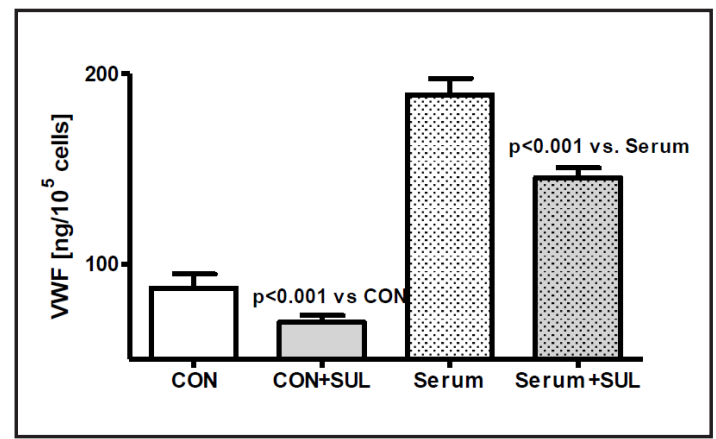

\section{Discussion}

Sulodexide is a drug with a confirmed anti-inflammatory and antithrombotic activity within the endovascular space [8]. It was found previously that it induces an antiinflammatory effect in human venous endothelial cells $[9,10,14]$. The results of our present study show that it also has a similar effect in human arterial endothelial cells, which have a different pattern 


\section{Cellular Physiology Cell Physiol Biochem 2016;40:1005-1012 \begin{tabular}{l|l|l} 
and Biochemistry & $\begin{array}{l}\text { DOI: 10.1159/000453157 } \\
\text { Published online: December 12, } 2016\end{array}$ & $\begin{array}{l}\text { (c) } 2016 \text { The Author(s). Published by S. Karger AG, Basel } \\
\text { www.karger.com/cpb }\end{array}$ \\
\hline
\end{tabular} \\ Sosińska et al.: Arterial Endothelium and Sulodexide}

of secretory activity than human venous endothelial cells (Breborowicz, unpublished data). It should be stressed that our experimental setting was different from that used previously in experiments on human endothelial cells with sulodexide $[9,10,14]$. We did not look at the secretory activity of the endothelial cells in the presence of sulodexide, but after their exposure to that drug. That means that the observed effects in our experiments were due to a change in the activity of genes caused by cell pretreatment with sulodexide. In fact we found that exposure of HAEC to sulodexide resulted in a decreased expression of genes responsible for the synthesis of IL6, VCAM-1 and VWF.

The results of our experiments show that sulodexide induces changes in the function of HAEC, which can result in slowing the progression of atherosclerotic changes in the arteries. Interleukin-6 blood levels correlate with dysfunction of the endothelial cells, arterial stiffness, and predict risk of vascular events $[17,18]$. Decreasing the IL-6 level in patients with PAD seems to be a desirable effect, preventing progression of the disease [19]. Previously, we found that sulodexide also inhibits IL-6 release from human venous endothelial cells [9]. In the present experiments we observed sulodexide-induced reduction of IL- 6 release from the unstimulated HAEC, cells stimulated with interleukin 1 (Fig. 1) or with PAD serum (Fig. 2). The decreased release of IL- 6 in HAEC may prevent activation of the interleukin-1 pathway, which is the final inflammatory step in the progression of atherosclerosis [20].

In physiological conditions there is minimal contact of the endothelial cells lining the vessels with blood leukocytes. Intravascular inflammation leads to activation of the endothelial cells, and one of the consequences of this state is the synthesis of VCAM-1 [21], which enables the adhesion of blood leukocytes to the surface of the endothelium. The adhesion of monocytes to endothelial cells, with the subsequent accumulation of these cells in the wall of arteries promotes the progression of atherosclerosis [22]. Previously, we found that serum obtained from patients with chronic venous disease enhances the release of ICAM-1 from venous endothelial cells, and that effect was prevented by simultaneous exposure to sulodexide [10]. A similar effect was observed in HAEC exposed to PAD serum, and again sulodexide treatment reduced VCAM-1 synthesis and secretion (Fig. 3). According to our observations sulodexide joins the large group of drugs which prevent progression of atherosclerosis through inhibition of formation of the endothelial adhesion proteins such as Tetrahydroxystilbene Glucoside [23] or Angiotensin-(1-7) [24].

Our results demonstrate that besides the anti-inflammatory action of sulodexide it also reduces the release of VWF from HAEC (Fig. 4). VWF produced in the endothelial cells plays a role in hemostasis, but excessive release of that protein predisposes the patient to thrombotic disorders, and promotes the progression of atherosclerosis [25]. Increased blood level of VWF is observed in patients with PAD [26]. We found that exposure of HAEC to PAD serum enhances the expression of the VWF gene in these cells, with a subsequent increased release of that protein into the medium. Simultaneous exposure to sulodexide resulted in the reduced effect of PAD serum on the secretion of VWF from HAEC (Fig. 4). Previously, Lekesiz et al. found that heparin, but not sulodexide, reduced the release of VWF from human venous endothelial cells in in vitro culture [27]. However, similarly as in our experiments, sulodexide reduced the expression of VFW genes [27]. The discrepancy between our results and data presented by Lekesiz et al. may be due to the fact that we performed experiments on arterial endothelial cells, which were exposed to sulodexide for a longer period of time.

In conclusion, we found that sulodexide reduces the proinflammatory and procoagulant effects in arterial endothelial cells caused by serum from patients with PAD. The observed changes in the secretory pattern of the cells were due to the reduced expression of genes responsible for the synthesis of IL-6, VCAM-1 and VWF. These observations suggest that sulodexide, due to its multidirectional action on endothelial cells, may slow down the progression of atherosclerosis and peripheral artery disease. 


\section{Cellular Physiology Cell Physiol Biochem 2016;40:1005-1012 \begin{tabular}{ll|l} 
DOI 10.1159/000453157 & $\begin{array}{l}\text { O 2016 The Author(s). Published by S. Karger AG, Basel } \\
\text { www.karger.com/cpb }\end{array}$ \\
\cline { 2 - 3 }
\end{tabular} \\ Sosińska et al.: Arterial Endothelium and Sulodexide}

\section{Acknowledgements}

Study was supported by grant from Poznan University of Medical Sciences.

\section{Disclosure Statement}

Dr Jasińska-Suminska is an employee of Alfa Wassermann Polska.

\section{References}

1 Giannotti G, Landmesser U: Endothelial dysfunction as an early sign of atherosclerosis. Herz 2007;32:568572.

2 Noble MIM, Drake-Holland AJ, Vink H: Hypothesis: arterial glycocalyx dysfunction is the first step in the atherothrombotic process. QJM 2008;101:513-518.

3 Cancel LM, Ebong EE, Mensah S, Hirschberg C, Tarbell JM: Endothelial glycocalyx, apoptosis and inflammation in an atherosclerotic mouse model. Atherosclerosis 2016;252:136-146.

4 Broekhuizen LN, Lemkes BA, Mooij HL, Meuwese MC, Verberne H, Holleman F, Schlingemann RO, Nieuwdorp M, Stroes ES, Vink H: Effect of sulodexide on endothelial glycocalyx and vascular permeability in patients with type 2 diabetes mellitus. Diabetologia 2010;53:2646-2655.

5 Mannello F, Ligi D, Raffetto JD: Glycosaminoglycan sulodexide modulates inflammatory pathways in chronic venous disease. Int Angiol 2014;33:236-242.

6 Crepaldi G, Rossi A, Coscetti G, Abbruzzese E, Calveri U, Calabro A: Sulodexide oral administration influences blood viscosity and fibrinolysis. Drugs Exp Clin Res 1992:18:189-195.

7 Corsi C, Bocci L, Cipriani C, Gazzini A, Marrapodi E: The effectiveness of glycosaminoglycans in peripheral vascular disease therapy: a clinical and experimental trial. J Int Med Res 1985;13:40-47.

8 Coccheri S: Biological and clinical effects of sulodexide in arterial disorders and diseases. Int Angiol 2014;33:263-274.

9 Ciszewicz M, Połubinska A, Antoniewicz A, Suminska-Jasinska K, Bręborowicz A: Sulodexide suppresses inflammation in human endothelial cells and prevents glucose toxicity. Transl Res 2009;153:118-123.

10 Urbanek T, Krasinski Z, Sumińska-Jasińska K, Baum E, Borej-Nowicka G, Begier-Krasińska B, Bręborowicz A: Sulodexide reduces the inflammatory reaction and senescence of endothelial cells in conditions involving chronic venous disease. Int Angiol 2016;35:140-147.

11 Andriuoli G, Mastacchi R, Barbanti M: Antithrombotic activity of glycosaminoglycan (sulodexide) in rats. Thromb Res 1984;34:81-86.

12 Tiozzo R, Cingi MR, Pietroangelo A, Albertazzi L, Calandra S, Milani MR: Effect of heparin-like compounds on the in vitro proliferation and protein synthesis of various cell types. Drug Res 1989;39:15-20.

13 Babal P, Kristova V, Kriska M: Decreased endothelial loss after Sulodexide administration assessed by in vitro vessel perfusion. Res Comm Pharm Toxicol 1996;1:119-126.

14 Gabryel B, Jarząbek K, Machnik G, Adamczyk J, Belowski D, Obuchowicz E, Urbanek T: Superoxide dismutase 1 and glutathione peroxidase 1 are involved in the protective effect of sulodexide on vascular endothelial cells exposed to oxygen-glucose deprivation. Microvasc Res 2016;103:26-35.

15 Ye J, Coulouris G, Zaretskaya I, Cutcutache I, Rozen S, Madden TL: Primer-BLAST: A tool to design targetspecific primers for polymerase chain reaction. Bioinformatics 2012;13:134.

16 Livak KJ, Schmittgen TD: Analysis of relative gene expression data using real-time quantitative PCR and 2- $\Delta \Delta$ CT method. Methods 2001;25:402-408.

17 Esteve E, Castro A, Lopez-Bermejo A, Vendrell J, Ricart W, Fernanzdez-Real JM: Serum interleukin-6 correlates with endothelial dysfunction in healthy men independently of insulin sensitivity. Diabetes Care 2007;30:939-945.

18 Mahmud A, Feely J: Arterial stiffness is related to systemic inflammation in essential hypertension. Hypertension 2005;46:1118-1122. 


\section{Cellular Physiology Cell Physiol Biochem 2016;40:1005-1012 \begin{tabular}{ll|l} 
and Biochemistry & $\begin{array}{l}\text { DOI: 10.1159/000453157 } \\
\text { Published online: December 12, } 2016\end{array}$ & $\begin{array}{l}\text { O 2016 The Author(s). Published by S. Karger AG, Basel } \\
\text { www.karger.com/cpb }\end{array}$ \\
\cline { 2 - 3 }
\end{tabular} \\ Sosińska et al.: Arterial Endothelium and Sulodexide}

19 Signorelli SS, Anzaldi M, Libra M, Navolanic PM, Malaponte G, Mangano K, Quattrochi C,Di Marco R, Fiore V, Neri S: Plasma levels of inflammatory biomarkers in peripheral arterial disease: results of a cohort study. Angiology 2016;9:870-874.

20 Ridker PM: From CRP to IL-6 to IL-1: moving upstream to identify novel targets for atherosclerosis. Clin Res 2016;118:145-156.

21 Libby P, DiCarli M, Weissleder R: The vascular biology of atherosclerosis and imaging targets. J Nucl Med 2010; 51: 33S-37S

22 Mestas J, Ley K: Monocyte-endothelial cell interactions in the development of atherosclerosis. Trends Cardiovasc Med 2008;18:228-232.

23 Yao W, Huang C, Sun Q Jing X, Wang H, Zhang W: Tetrahydroxystilbene glucoside protects against oxidized LDL-induced endothelial dysfunction via regulating vimentin cytoskeleton and its colocalization with ICAM-1 and VCAM-1. Cell Physiol Biochem 2014;34:1442-1454.

24 Liang B, Wang X, Zhang N, Yang H, Bai R, Liu M, Bian Y, Xiao C, Yang Z: Angiotensin-(1-7) Attenuates Angiotensin II-Induced ICAM-1, VCAM-1, and MCP-1 Expression via the MAS Receptor Through Suppression of P38 and NF-кB Pathways in HUVECs. Cell Physiol Biochem 2015;35:2472-2482.

25 Blann AD: Plasma von Willebrand factor, thrombosis, and the endothelium: the first 30 years. Thromb Haemost 2006;95:49-55.

26 Reich LM, Heiss G, Boland LL, Hirsch AT, Wu K, Folsom AR: Ankle-brachial index and hemostatic markers in the Atherosclerosis Risk in Communities (ARIC) study cohort. Vasc Med 2007;12:267-273.

27 Lekesiz K, Naumnik B, Borysewicz-Sanczyk H, Koc-Zorawska E, Mysliwiec M: Effect of unfractionated heparin, enoxaparin and sulodexide on relations between secretion and expression of OPG, RANL and vWF in HUVEC. Folia Histochem Cytobiol 2013;51:156-163. 